\title{
Biomarker Investigations in Adult Female Perch (Perca fluviatilis) From Industrialised Areas in Northern Sweden in 2003
}

\author{
Tomas Hansson • Wenche Hansen • \\ Ulla Tjärnlund $\cdot$ Lennart Balk $\cdot$ Bengt-Erik Bengtsson
}

Received: 24 July 2013/ Accepted: 16 November 2013/Published online: 3 December 2013

(C) Springer Science+Business Media New York 2013

\begin{abstract}
Since the new millennium, a notion has developed in certain parts of society that environmental pollutants and their associated effects are under control. The primary objective of this investigation, performed in 2003, was to test whether this was actually the case in an industrialised region in the County of Västernorrland in northern Sweden with well-documented environmental pollution from past and present activities. This was performed by measuring a moderate battery of simple biomarkers in adult female perch at several stations. The point sources included sewage-treatment plants, pulp and paper mills, as well as other industries. The biomarkers included growth, somatic indices, gonad maturation status, gonad pigmentation, fin erosion, skin ulcers, and ethoxyresorufin$O$-deethylase (EROD) activity in the liver. The results showed that the environmental pollutants and their associated effects were not under control. In fact, the health of the perch was impaired at all of the polluted stations. Many responses were unspecific with respect to underlying cause, whereas some effects on EROD activity and gonad
\end{abstract}

Electronic supplementary material The online version of this article (doi:10.1007/s00244-013-9974-5) contains supplementary material, which is available to authorized users.

T. Hansson $(\bowtie) \cdot$ U. Tjärnlund · L. Balk · B.-E. Bengtsson

Department of Applied Environmental Science (ITM),

Stockholm University, 10691 Stockholm, Sweden

e-mail: tomas.hansson@itm.su.se

W. Hansen

Department of Applied Science and Design (NVD), Mid Sweden

University, 85170 Sundsvall, Sweden

W. Hansen

Environmental Protection Unit, Länsstyrelsen Västernorrland, 87127 Härnösand, Sweden maturation status were attributed to historical creosote pollution and current kraft pulp mill effluents, respectively. The data presented may also be used as reference values for future investigations of health effects in perch.

The second half of the twentieth century has seen a growing environmental concern among scientists, natural resource managers, and decision makers. During this time, much research and monitoring activities has focused on environmental pollution. One type of environmental monitoring is biomarker investigations of fish in polluted areas, and numerous cases have been reported from all over the world (see e.g., van der Oost et al. 2003 and references therein). Since the new millennium, however, a notion has developed in certain parts of society that environmental pollutants and their associated effects are under control (Forsberg 2009). To test whether this was actually the case in an industrialised region in Sweden with well-documented environmental pollution from past and present activities, we measured biomarkers in adult female perch (Perca fluviatilis) at several locations in 2003. Owing to limited resources, the investigation was restricted to a few easily measured biomarkers reflecting the health status of perch. They included growth, somatic indices, gonad maturation status, gonad pigmentation, fin erosion, skin ulcers, and ethoxyresorufin$O$-deethylase (EROD) activity in the liver.

The results represent a "snapshot" of the situation in 2003. Information about past and present pollution and human activities in the investigated areas is given with some detail to provide a background for the observed effects on the perch. This background may also be representative for the situation in other parts of the industrialised world. When possible, we have linked observed effects to certain types of pollution. 
Perch has a long history as being a sentinel species for anthropogenic pollution (Balk et al. 1996; Sandström et al. 2005; Hansson et al. 2006a; Hanson et al. 2009). It has a wide distribution in fresh and brackish waters in the northern hemisphere (Craig 1987) and is relatively easy to catch. It is large enough for inner organs and blood to be sampled for physiological and biochemical analysis. It is also relatively sedentary, which has been explicitly shown in at least three investigations (Craig 1974; Kipling and Le Cren 1984; Böhling and Lehtonen 1985). Informative is also the large number of investigations of perch in pollution gradients (Andersson et al. 1988; Ericson et al. 1998; Hansson et al. 2006b; Linderoth et al. 2006) where a graded response was obtained, which would be impossible if the perch migrated widely.

The County of Västernorrland, situated at the east coast of northern Sweden, has an industrial history spanning more than two centuries. During the nineteenth century, sawmills dominated the basic industry, but shipyards and glassworks were also important. At some of the sawmills, the wood was impregnated. The impregnation agents consisted of metal salts, creosote, or chlorophenols. Some of the chlorophenol agents were contaminated by dioxins. Increased levels of metals, polycyclic aromatic hydrocarbons (PAHs), and dioxins are thus encountered at former impregnation sites. Investigations performed so far have shown that problems with dioxin pollution at former sawmills are both large and resource-consuming with respect to remediation (Anonymous 2010).

In the beginning of the twentieth century, many sawmills struggled with low profitability. As an alternative, focus was turned to production of cellulose, and the area experienced a tremendous expansion of pulp mills. The County of Västernorrland became a centre for cellulose production, and 30 new pulp mills were established between 1870 and 1930. A common byproduct of the sulphite method for pulp production was roasted pyrite ash, which was often heavily contaminated with metals. Previously, when the hazardous properties of roasted pyrite ash were not fully known, it was used i.a. as filling material (Anonymous 2010).

During the twentieth century, a number of other activities associated with cellulose production and other energyconsuming industry were located in the County of Västernorrland, including board factories, impregnation works, silicon and aluminium smelters, wiredrawing works, and production of acetic acid, ammonia, butanol, carbide, chloralkali, chlorate, epoxide, ethyl acetate, nitric acid, sulphite alcohol, sulphuric acid, organic chemicals, artificial silk, explosives, fertilizers, graphite electrodes, mineral wool, pesticides, plastic, yeast feed, etc. Engineering workshops were also established to support the network of process industry. This industrial development has resulted in numerous polluted sites in the County of Västernorrland. However, special concern about the environment did not arise until the early 1960s (Anonymous 2010).

\section{Materials and Methods}

\section{Sampling Stations}

The investigated stations (Fig. 1; Table 1) are all situated in the County of Västernorrland in northern Sweden. Forests and mountains dominate the area, whereas some agricultural land surrounds towns and villages.

\section{Bollstafjärden}

Bollstafjärden is a bay that falls into the river Ångermanälven. Station 1-Dynäs upper (Fig. 1) is situated $1.1 \mathrm{~km}$ downstream from the sawmill Bollsta sågverk [Svenska Cellulosa Aktiebolaget (SCA)] and $1.4 \mathrm{~km}$ upstream from the pulp mill Mondi Dynäs $\mathrm{AB}$. In addition to this, the Malmbergskajen sewage-treatment plant (STP) has its discharge at this station. Station 2-Dynäs lower (Fig. 1) is situated $0.4 \mathrm{~km}$ downstream from Mondi Dynäs AB.

Bollsta sågverk had a production of $359,000 \mathrm{~m}^{3}$ wood products in 2003. Mondi Dynäs AB, which is an integrated pulp and paper mill, produced 185,220 tonnes of kraft paper from unbleached kraft pulp in 2003. The Malmbergskajen STP has been in operation since 1971 and had a load of 2250 person equivalents (pe) in 2003. The upper part of Bollstafjärden is largely polluted with PAHs from historical activities. Sediment concentrations of $16 \mathrm{PAHs}$ ranged from $<1$ to $>8000 \mathrm{mg} / \mathrm{kg}$ dry substance (Anonymous 2009). Some of the highest concentrations were found directly northwest of station 1-Dynäs upper. The origin of this pollution is most probably historical wood impregnation with creosote, which consists of $\sim 90 \%$ of PAHs (Sundström et al. 1986).

\section{Utansjö}

Utansjö is a municipality situated on the shore of the lower part of the river Angermanälven. Station 3-Utansjö upper (Fig. 1) is situated right at the southern abutment of the E4 highway bridge Högakustenbron. Station 4-Utansjö middle (Fig. 1) is situated $0.8 \mathrm{~km}$ downstream from 3-Utansjö upper and directly west of the discharge from the Mörtsal STP. Station 5-Utansjö lower (Fig. 1) is situated $2.5 \mathrm{~km}$ downstream from 4-Utansjö middle and $0.8 \mathrm{~km}$ downstream from the pulp mill Utansjö bruk.

The first pulp mill in Utansjö was built in 1900. It was a sulphite pulp mill, and the capacity was 10,000 tonnes/year, 
Fig. 1 The investigated stations in the County of Västernorrland (Sweden): 1-Dynäs upper, 2-Dynäs lower, 3-Utansjö upper, 4-Utansjö middle,

5-Utansjö lower, 6-Vivstavarv,

7-Skönvik, 8-Sundsvall,

9-Åstön (reference). The stations 1-Dynäs upper and 2-Dynäs lower are both situated in the bay Bollstafjärden.

Arrows indicate the direction of the current in the river Ångermanälven. The investigated area is dominated by forests and mountains. Some agricultural land surrounds towns and villages

Table 1 Stations and number of sampled adult female perch

a World Geodetic System 1984

b SWEdish REference Frame 1999, Transverse Mercator RH 2000

${ }^{c}$ Sexually mature (SM) and sexually immature (SIM) females specified within parentheses: (SM+SIM)

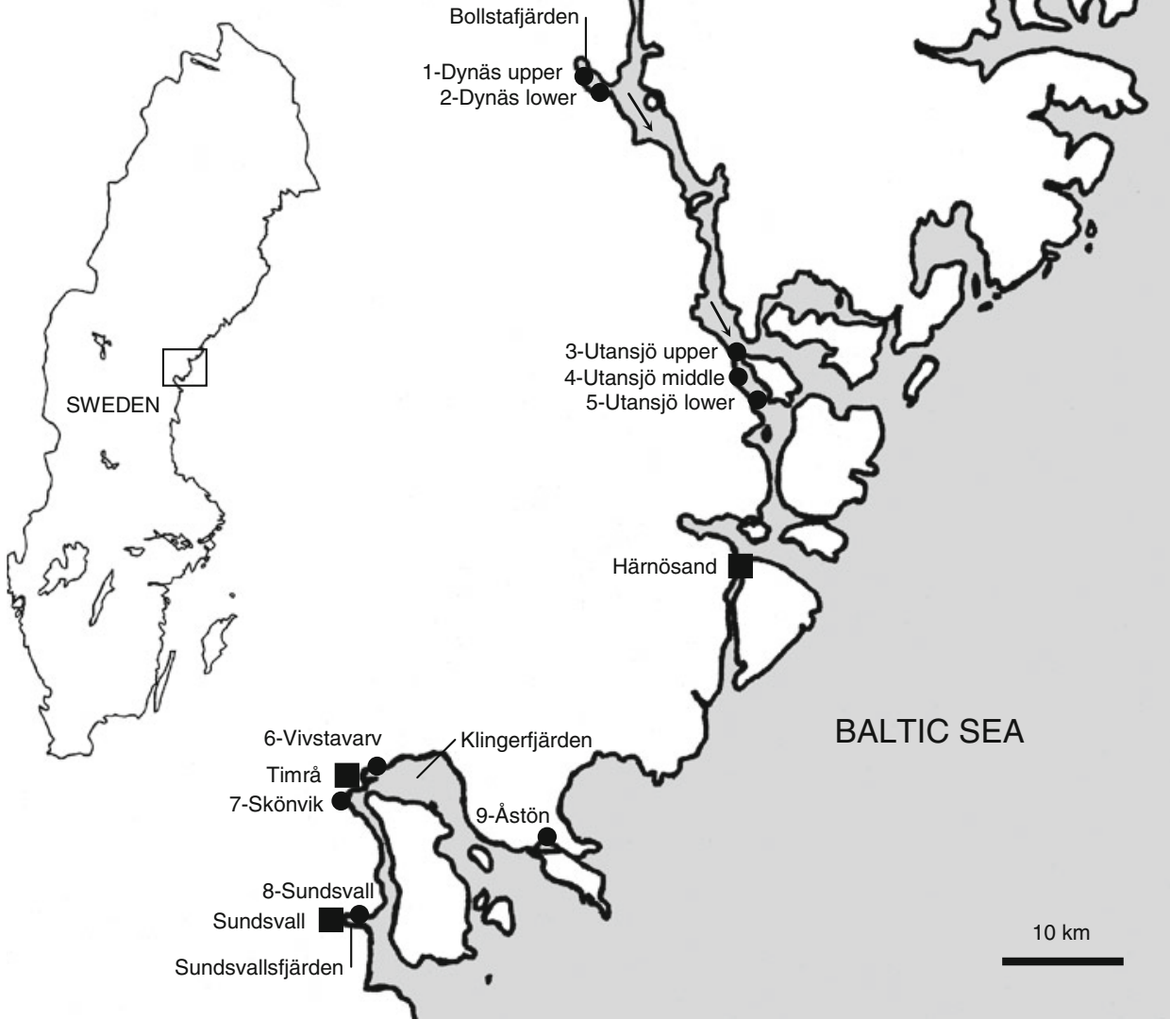

\begin{tabular}{llll}
\hline Station & $\begin{array}{l}\text { Coordinates in } \\
\text { WGS 84 }\end{array}$ & $\begin{array}{l}\text { Coordinates in SWEREF } \\
99 \text { TM RH 2000 }\end{array}$ & $\begin{array}{l}\text { No. of } \\
\text { specimens }^{\mathrm{c}}\end{array}$ \\
\hline 1-Dynäs upper & $62.98479 \mathrm{~N}$ & $6986764 \mathrm{~N}$ & 34 \\
& $17.69872 \mathrm{E}$ & $636738 \mathrm{E}$ & $(29+5)$ \\
2-Dynäs lower & $62.97473 \mathrm{~N}$ & $6985697 \mathrm{~N}$ & 7 \\
& $17.72361 \mathrm{E}$ & $638046 \mathrm{E}$ & $(1+6)$ \\
3-Utansjö upper & $62.79262 \mathrm{~N}$ & $6965887 \mathrm{~N}$ & 4 \\
& $17.93158 \mathrm{E}$ & $649506 \mathrm{E}$ & $(4+0)$ \\
4-Utansjö middle & $62.78614 \mathrm{~N}$ & $6965171 \mathrm{~N}$ & 8 \\
& $17.93389 \mathrm{E}$ & $649657 \mathrm{E}$ & $(7+1)$ \\
5-Utansjö lower & $62.76608 \mathrm{~N}$ & $6962964 \mathrm{~N}$ & 8 \\
& $17.94539 \mathrm{E}$ & $650346 \mathrm{E}$ & $(5+3)$ \\
6-Vivstavarv & $62.49631 \mathrm{~N}$ & $6931716 \mathrm{~N}$ & 19 \\
& $17.37213 \mathrm{E}$ & $622200 \mathrm{E}$ & $(19+0)$ \\
7-Skönvik & $62.47129 \mathrm{~N}$ & $6928845 \mathrm{~N}$ & 15 \\
& $17.32716 \mathrm{E}$ & $619984 \mathrm{E}$ & $(8+7)$ \\
8-Sundsvall & $62.39128 \mathrm{~N}$ & $6919945 \mathrm{~N}$ & 11 \\
& $17.33205 \mathrm{E}$ & $620558 \mathrm{E}$ & $(9+2)$ \\
9-Åstön (reference) & $62.43834 \mathrm{~N}$ & $6925827 \mathrm{~N}$ & 27 \\
& $17.65417 \mathrm{E}$ & $636989 \mathrm{E}$ & $(27+0)$ \\
\hline
\end{tabular}

which increased to 20,000 tonnes/year in 1919. In 1965, the process was converted to magnefite (magnesium sulphite). In the early 1970s, a groundwood mill was established on the premises with a capacity of 80,000 tonnes of mechanical wood pulp/year. In 1999, the production was 62,000 tonnes of magnefite pulp and 75,000 tonnes of mechanical wood pulp (Heinemo 2001). Production continued until 2008, when the pulp mill was closed down 
(Anonymous 2010). The premises also included an industry harbour. Pilot investigations did not find any significant pollution by roasted pyrite ash in the area (Heinemo 2001). The Mörtsal STP has been in operation since 1973 and had a load of 550 pe in 2003. The area also contains much historical (nineteenth century) pollution from sawmills (Anonymous 2010) and perhaps also a former (eighteenth and nineteenth century) ironworks (Heinemo 2001).

\section{Vivstavarv}

Vivstavarv is an old industry area situated on the shore of the bay Klingerfjärden (Baltic Sea). Station 6-Vivstavarv (Fig. 1) is situated close to the paper mill Wifstavarfs AB, and the Näs STP has its discharge at this station. In addition, the former industry area of Fagervik is situated directly east of 6-Vivstavarv.

Wifstavarfs $\mathrm{AB}$, which was closed down in 2007, produced paper from pulp received by way of pipeline from the nearby Östrand pulp mill (SCA) and had a production of $\sim 145,000$ tonnes in 2003. The Näs STP has been in operation since 1972 and had a load of 10,875 pe in 2003. Station 6-Vivstavarv has a long history of heavy industrial activity, including shipping, sawmills, and a kraft pulp mill (Anonymous 2010).

\section{Skönvik}

Skönvik is a small inlet of the bay Klingerfjärden (Baltic Sea). Station 7-Skönvik (Fig. 1) is situated in this inlet, where the Östrand pulp mill (SCA) has its discharge. The Östrand pulp mill, which produces bleached kraft pulp and chemithermomechanical pulp (CTMP), had a production of 395,529 tonnes of bleached kraft pulp and 69,732 tonnes of CTMP in 2003. Historically, sawmills and a chloralkali industry have also been located in the Östrand industrial area (Anonymous 2010).

\section{Sundsvall}

Sundsvall is a city with $\sim 49,000$ inhabitants in 2003. It is situated on the innermost shore of the bay Sundsvallsfjärden (Baltic Sea). The E4 highway passes through the city, and numerous industries are located on the shore of Sundsvallsfjärden. Station 8-Sundsvall (Fig. 1) is situated close to the Sundsvall harbour and the Ortviken paper mill (SCA). The Tivoliverket STP has its discharge directly west of this station.

The Ortviken sulphite pulp mill was established in 1906 with a capacity of 15,000 tonnes/year. During the 1940s, the capacity was increased to 45,000 tonnes/year and in 1967 to
90,000 tonnes/year. The pulp mill was closed down in 1984 . A newsprint mill with mechanical wood pulp as a basis was established on the premises in 1958 and is today, after several extensions, one of the largest in Europe (Heinemo 2001). The production was 349,189 tonnes of newsprint and 378,046 tonnes of light-weight coated paper in 2003. Pilot investigations found increased metal concentrations in the sediment close to the quay, which are suspected to originate from pollution from roasted pyrite ash (Heinemo 2001). The Tivoliverket STP has been in operation since 1971 and had a total load of 63,300 pe $(46,300$ pe from households and 17,000 pe from industries) in 2003.

\section{Åstön (Reference)}

Åstön is an island at the Baltic Sea coast, and station 9-Åstön (Fig. 1) is situated $\sim 15 \mathrm{~km}$ west-southwest of 6-Vivstavarv in the strait Tynderösundet north of Åstön. It is a rural area without industries or other point sources of pollution. 9-Åstön is similar to reference stations in other investigations of perch with respect to growth (Linderoth et al. 2006) and somatic indices (Noaksson et al. 2004; Hansson et al. 2006a; Linderoth et al. 2006). Comparison of liver ethoxyresorufin- $O$-deethylase (EROD) activity with that of fish from reference stations in other investigations was not possible owing to method differences. All of the adult females at 9-Åstön produced eggs.

\section{Chemicals}

Bovine serum albumin (A4378), ethoxyresorufin (E3763), reduced nicotinamide adenine dinucleotide phosphate (NADPH, N7505, $98 \%$ ), resorufin (R3257), sucrose [pro analysi (p.a.) grade], and Trizma hydrochloride (T3253) were purchased from Sigma (St. Louis, MO, USA). Copper sulphate $\left(\mathrm{CuSO}_{4}\right.$, p.a. grade), disodium carbonate $\left(\mathrm{Na}_{2} \mathrm{CO}_{3}\right.$, p.a. grade), Folin-Ciocalteu's phenol reagent (1.09001.0500), potassium sodium tartrate (p.a. grade), and sodium hydroxide $(\mathrm{NaOH}$, p.a. grade) were purchased from Merck (Darmstadt, Germany). Oxyletten (oxygen tablets) were purchased from Hans Brustmann GmbH \& Co. KG (Östrich-Winkel, Germany).

\section{Sampling of Perch}

The perch were caught overnight with gill nets (mesh size 30-34 mm) on different occasions during the period October 12 through November 7, 2003. Surviving specimens were immediately carefully released from the net, placed in a fish tank with water from the sampling site, and transported to a storage room. Oxygen tablets (Oxyletten) were used to ensure sufficient oxygen supply during 
transport. In the storage room, tanks with the perch were kept at $4{ }^{\circ} \mathrm{C}$ during 1-3 days before dissection to allow bile accumulate in the gall bladder. During this time, a water pump circulated the water to ensure sufficient oxygen supply. Dissection and sampling was performed at $4{ }^{\circ} \mathrm{C}$. The sampling of each specimen was completed before the next specimen was sampled. The number of specimens is listed in Table 1. The perch were killed by a blow on the head after which length, weight, gonad weight, liver weight, gonad maturation status, gonad pigmentation, fin erosion, and skin ulcers were recorded. The ulcers were clearly distinguishable from net injuries and other types of lesions. To obtain a homogeneous material, only adult females $(211-358 \mathrm{~mm})$ were used in the investigation, whereby individuals with a maturing gonad were referred to as sexually mature (SM) and those with a nonmaturing gonad as sexually immature (SIM). As discussed later in the text in Gonad Maturation Status, the occurrence of SIM females that are adult by size is considered unnatural. Hence, such occurrence is presented here as a biological effect even when the frequency of SM females did not differ statistically from that of those from the reference station. Bile was sampled as described by Pettersson et al. (2007). For the measurement of liver EROD activity, a slice (1-1.5 g) from the central part of the liver was dissected, weighed, and snap-frozen in liquid nitrogen. Age was determined by analysis of the left and right opercular bones according to the method described by Le Cren (1947). Somatic growth (SG), somatic condition index (SCI), gonadosomatic index (GSI), and liver somatic index (LSI) were calculated for each specimen (Table 2).
Normalisation of GSI and LSI With Respect

to Sampling Date

Noaksson et al. (2004) measured the cyclic variation in GSI and LSI in perch in a reference lake in central Sweden during 1 entire year. Data from their investigation suggested an almost linear growth of the gonad in SM females and of the liver in SM and SIM females during September through November. Based on these data, the following equations were used to normalise GSI and LSI with respect to sampling date:

$$
\begin{aligned}
\mathrm{GSI}_{\text {normalised }} & =\mathrm{GSI}_{\text {measured }}+0.0757 \times \Delta \text { Time }(\mathrm{SM} \text { females }) \\
\mathrm{LSI}_{\text {normalised }} & =\mathrm{LSI}_{\text {measured }}+0.0130 \times \Delta \text { Time }(\text { all females }) .
\end{aligned}
$$

The unit of time was days, which means that GSI increased by $0.0757 \%$ units/day and that LSI increased by $0.0130 \%$ units/day. The normalised values corresponded to the values that would have been obtained if all specimens were sampled on the same day, which we chose to be October 28, 2003 (in the middle of our sampling period).

\section{EROD Activity in the Liver}

The dissected liver slice was partially thawed, cut into pieces, and homogenised in four volumes (dilution to $20 \%$ ) of $0.25 \mathrm{M}$ sucrose at $0{ }^{\circ} \mathrm{C}$ with a 9-mL (size 21) Potter-Elvehjem homogeniser (VWR International, Stockholm, Sweden) using four up and down strokes at 420 revolutions $/ \mathrm{min}$. The homogenate was centrifuged at $9000 \times g$ at $4{ }^{\circ} \mathrm{C}$ for 10 min to obtain an S9 supernatant. Aliquots of the S9 supernatant were transferred to cryotubes, which were snap-
Table 2 Measured variables in adult female perch

\footnotetext{
${ }^{a}$ Normalised with respect to length

b Somatic weight $=$ total weight minus gonad weight

c Normalised with respect to sampling date

\begin{tabular}{|c|c|c|}
\hline Variable & Unit & Explanation and/or reference \\
\hline Length & Millimetre & Total length (including entire tail fin) \\
\hline Weight & Gram & Total weight (including gut contents) \\
\hline Age & Year & $\begin{array}{l}\text { Determined by analysis of the } \\
\text { left and right opercular bones } \\
\text { according to Le Cren (1947) }\end{array}$ \\
\hline Somatic growth $^{\mathrm{a}}(\mathrm{SG})$ & Gram/year & Somatic weight $\mathrm{b} / \mathrm{age}$ \\
\hline $\mathrm{SCI}$ & Usually given without unit & $\begin{array}{r}100 \times \text { somatic weight/cubed } \\
\text { length in cubic centimetres }\end{array}$ \\
\hline $\begin{array}{l}\text { Gonad maturation } \\
\text { status }\end{array}$ & SM or SIM & $\begin{array}{l}\text { SIM females are not preparing for } \\
\text { spawning } \\
\text { next year, and } \text { GSI }_{\text {SIM }}<1.0 \%\end{array}$ \\
\hline $\mathrm{GSI}^{\mathrm{c}, \mathrm{d}}$ & Percent of somatic weight & $100 \times$ gonad weight/somatic weight \\
\hline $\operatorname{LSI}^{\mathrm{c}, \mathrm{d}}$ & Percent of somatic weight & $100 \times$ liver weight/somatic weight \\
\hline $\begin{array}{l}\text { Specific EROD } \\
\text { activity }^{\mathrm{d}} \text { in the liver }\end{array}$ & $\begin{array}{l}\text { Picomol per minute and } \\
\text { milligram } S 9 \text { protein }\end{array}$ & Burke and Mayer (1974) \\
\hline Gonad pigmentation & $\begin{array}{l}\text { Normal, decreased (pale), or } \\
\text { increased }\end{array}$ & \\
\hline Fin erosion & $\begin{array}{l}\text { Little-medium }(+), \text { medium } \\
(++), \text { or much }(+++)\end{array}$ & \\
\hline Skin ulcers & Yes or no & \\
\hline
\end{tabular}

${ }^{d}$ Reported for SM females only
} 
frozen and stored in liquid nitrogen until measurement. Liver EROD activity was measured according to the method described by Burke and Mayer (1974). The formation of resorufin was measured with a JASCO FP-777 spectroflourometer (Tokyo, Japan) at an excitation wavelength of $530 \mathrm{~nm}$ and an emission wavelength of $583 \mathrm{~nm}$. The samples were measured in duplicates, and the results were expressed as $\mathrm{pmol}$ resorufin formed/min and $\mathrm{mg} \mathrm{S} 9$ protein. The $\mathrm{S} 9$ protein concentration was measured in duplicates according to Lowry et al. (1951) with a Varian Cary 50 UV/Vis Spectrophotometer (Amsterdam, The Netherlands) and with bovine serum albumin as a standard.

\section{Statistics}

A regression model with the stations represented as dummy variables and with robust variance estimates (Huber 1967; White 1980, 1982) was fitted to the data for the variables SG, SCI, GSI, LSI, and EROD activity. Shapiro-Wilk's normality test and Bartlett's test for equal variances, as well as diagnostic plots, were used to ensure that the requirements for normality and homoscedasticity were fulfilled. For GSI, only SM females were included in the analysis. For SG and EROD activity, the model was fitted to logarithm-transformed data, and for LSI the model was fitted to square root-transformed data. The results were then back-transformed to the original quantity. For SG, length was included as a covariate in the model, and the results were reported as predicted values for a length of $27 \mathrm{~cm}$ (the average length of the perch). For LSI and EROD activity, gonad maturation status (SM/SIM) was included in the model as a dummy variable, and the results were reported as predicted values for SM females. For all variables, each station was compared with 9-Åstön (reference). The respective means of SG, SCI, GSI, LSI, and EROD activity were compared with the Wald test, whereas the proportions of SM females were compared with Fisher's exact test. For all variables, significance was determined after $p$-value adjustment (not shown) for the number of comparisons with the reference station according to Holm (1979). An adjusted $p$-value $<0.05$ was considered significant. The bars in the figures represent means, and the error bars represent $95 \%$ confidence intervals (CIs). For the proportions of SM females, exact CIs were calculated according to the binomial distribution. The software Intercooled Stata 9.2 (StataCorp; College Station, TX, USA) was used for the analyses.

\section{Results}

Bollstafjärden

Station 1-Dynäs upper was characterised by $15 \%$ occurrence of SIM females (Fig. 6), $30 \%$ decreased GSI in SM females
(Fig. 5), and $80 \%$ increased liver EROD activity (Fig. 4). Station 2-Dynäs lower was characterised by $22 \%$ decreased SG (Fig. 2) and an $86 \%$ decrease in the frequency of SM females (Fig. 6). (Six of the seven specimens were SIM.) The Dynäs area as a whole was characterised by more fin erosion than seen at the reference station (Table 3).

Utansjö

Station 3-Utansjö upper was characterised by $30 \%$ decreased SG (Fig. 2) and $164 \%$ increased liver EROD activity (Fig. 4). Station 4-Utansjö middle was characterised

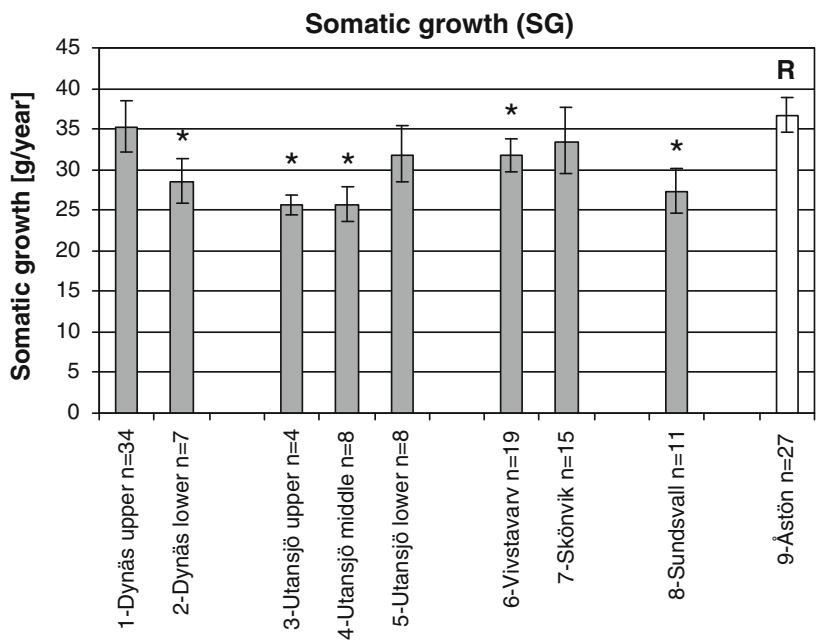

Fig. 2 SG in adult female perch. Predicted values for a length of $27 \mathrm{~cm}$ (the average length of the perch). Geometric mean $\pm 95 \% \mathrm{CI}$. $R$ reference, * significantly different from reference

Table 3 Results of four investigated variables in adult female perch

\begin{tabular}{|c|c|c|c|c|c|}
\hline Station & $n^{\mathrm{a}}$ & $\operatorname{LSI}^{\mathrm{b}}(\%)$ & $\begin{array}{l}\text { Gonad } \\
\text { pigmentation }\end{array}$ & $\begin{array}{l}\text { Fin } \\
\text { erosion }\end{array}$ & $\begin{array}{l}\text { Skin } \\
\text { ulcers }\end{array}$ \\
\hline 1-Dynäs upper & 34 & $1.62 \pm 0.11$ & Normal & ++ & No \\
\hline 2-Dynäs lower & 7 & $1.42 \pm 0.21$ & Normal & ++ & No \\
\hline $\begin{array}{l}\text { 3-Utansjö } \\
\text { upper }\end{array}$ & 4 & $1.37 \pm 0.18$ & $\begin{array}{l}\text { Decreased } \\
\text { (pale) }\end{array}$ & ++ & No \\
\hline $\begin{array}{l}\text { 4-Utansjö } \\
\text { middle }\end{array}$ & 8 & $1.51 \pm 0.13$ & $\begin{array}{l}\text { Decreased } \\
\text { (pale) }\end{array}$ & ++ & No \\
\hline $\begin{array}{l}\text { 5-Utansjö } \\
\text { lower }\end{array}$ & 8 & $1.45 \pm 0.23$ & $\begin{array}{l}\text { Decreased } \\
\text { (pale) }\end{array}$ & ++ & No \\
\hline 6-Vivstavarv & 19 & $1.55 \pm 0.11$ & Increased & ++ & Yes \\
\hline 7-Skönvik & 15 & $1.58 \pm 0.19$ & Normal & ++ & No \\
\hline 8-Sundsvall & 11 & $1.53 \pm 0.11$ & Normal & +++ & No \\
\hline $\begin{array}{l}\text { 9-Åstön } \\
\text { (reference) }\end{array}$ & 27 & $1.65 \pm 0.08$ & Normal & + & No \\
\hline
\end{tabular}

${ }^{\text {a }}$ Number of specimens

b Predicted values for SM females. Mean $\pm 95 \%$ CI. LSI did not differ significantly between any of the stations and the reference 
by $30 \%$ decreased SG (Fig. 2) and a $12 \%$ occurrence of SIM females (Fig. 6). Station 5-Utansjö lower was characterised by $38 \%$ occurrence of SIM females (Fig. 6). The Utansjö area as a whole was characterised by $12-19 \%$ decreased SCI (Fig. 3), pale gonads (Table 3), and more fin erosion than at the reference station (Table 3). The data from Utansjö indicated that differences in the biological effects in the perch were possible to distinguish when the distance between stations was approximately $\geq 1 \mathrm{~km}$.

\section{Vivstavary}

Station 6-Vivstavarv was characterised by $14 \%$ decreased SG (Fig. 2), $6 \%$ decreased SCI (Fig. 3), $26 \%$ decreased

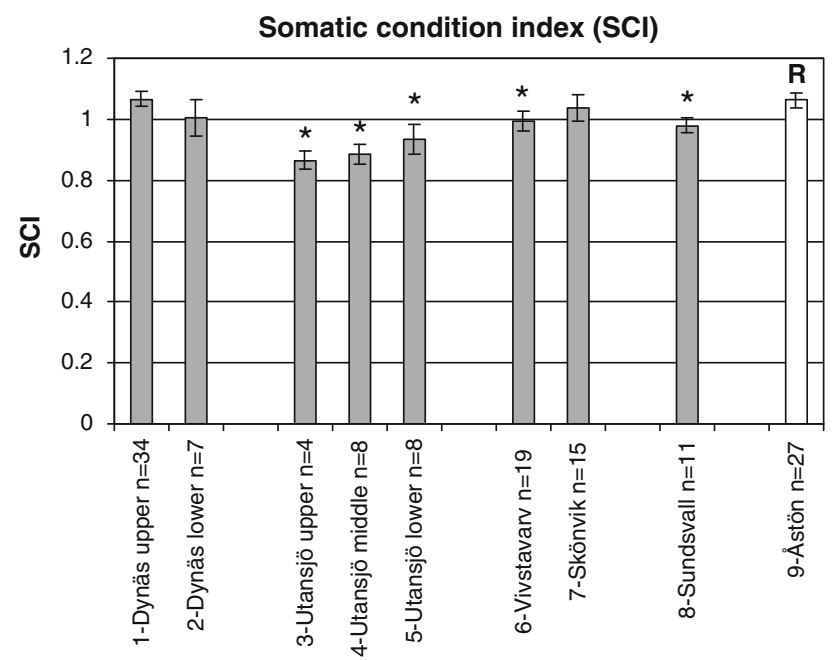

Fig. 3 SCI in adult female perch. Arithmetic mean $\pm 95 \%$ CI. $R$ reference, * significantly different from reference

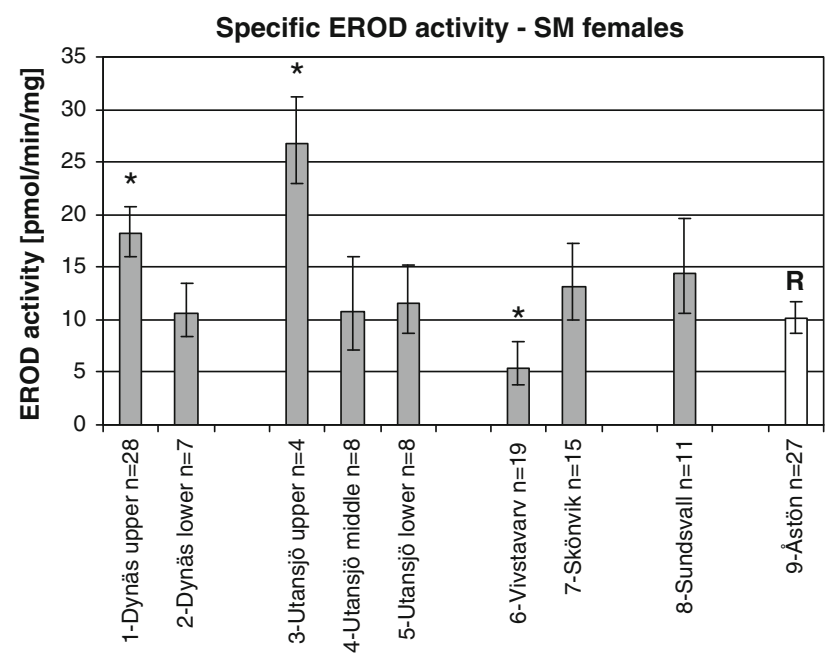

Fig. 4 Specific EROD activity in liver of adult female perch. Predicted values for SM females. Geometric mean $\pm 95 \%$ CI. $R$ reference, * significantly different from reference
GSI in SM females (Fig. 5), $46 \%$ decreased liver EROD activity (Fig. 4), increased gonad pigmentation (Table 3), and more fin erosion than at the reference station (Table 3). Moreover, all specimens at 6-Vivstavarv had skin ulcers with a diameter $\leq 1 \mathrm{~cm}$ (Table 3 ).

Skönvik

Station 7-Skönvik was characterised by a $47 \%$ decreased frequency of SM females (Fig. 6), $41 \%$ decreased GSI in SM females (Fig. 5), and more fin erosion than at the reference station (Table 3 ).

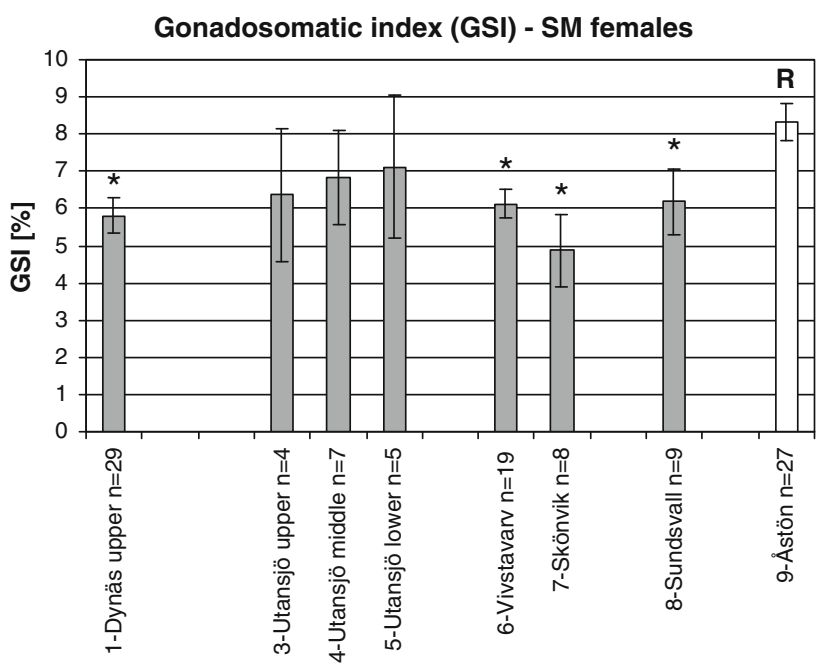

Fig. 5 GSI in SM adult female perch. Arithmetic mean $\pm 95 \%$ CI. $R$ reference, * significantly different from reference

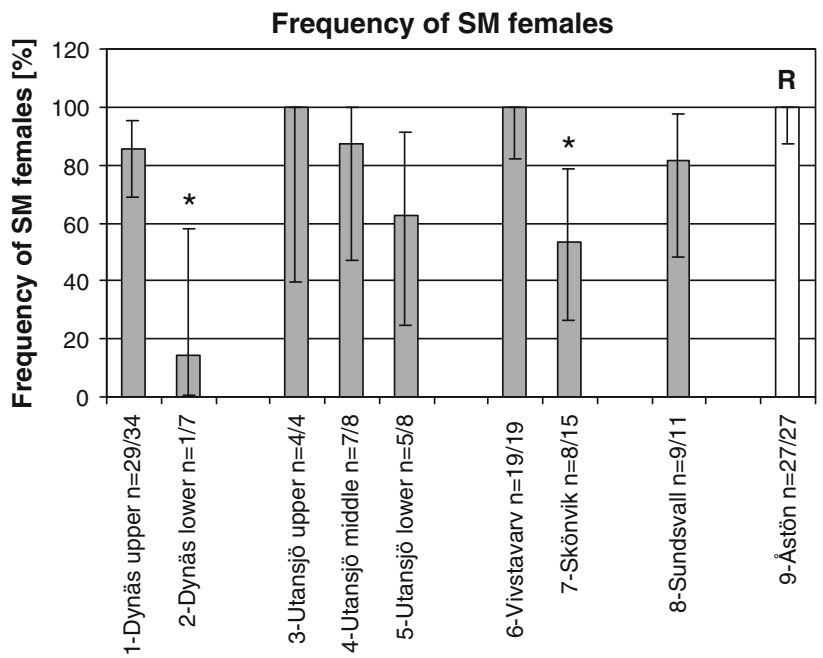

Fig. 6 Frequency of SM adult female perch. Proportion $\pm 95 \%$ CI. $R$ reference, * significantly different from reference 
Sundsvall

Station 8-Sundsvall was characterised by $26 \%$ decreased SG (Fig. 2), $8 \%$ decreased SCI (Fig. 3), $18 \%$ occurrence of SIM females (Fig. 6), $26 \%$ decreased GSI in SM females (Fig. 5), and much more fin erosion than at the reference station (Table 3).

\section{Confounding Variables}

A difference between SM and SIM females was found for LSI and EROD activity. On average, LSI was $34 \%$ lower in SIM females than in SM females, whereas EROD activity was $57 \%$ higher in SIM than in SM females. For the other investigated variables, no differences between SM and SIM females were found. SG was positively related to length with an increment of $\sim 2.6 \mathrm{~g} / \mathrm{year} / \mathrm{cm}$. By including gonad maturation status (SM/SIM) and length in the respective statistical analyses, their confounding effects were eliminated.

\section{Discussion}

Growth and Somatic Indices

SG, SCI, GSI, and LSI are all unspecific biomarkers, giving an integrated measure of effects of ambient stressors, which may have occurred in a complex mixture at the polluted stations in this investigation. The absolute values of these biomarkers were always lower at the polluted stations than at the reference station. There was, however, no particular pattern for those differences that were statistically significant. Decreased growth and decreased somatic indices in perch and other fish have been observed in numerous investigations of effects of environmental pollutants (see Hansson et al. 2006a; Linderoth et al. 2006 and references therein). In 1998, decreased growth in perch was observed along a PAH gradient in the Sundsvall area (Ericson et al. 1998).

\section{Gonad Maturation Status}

In this investigation, all females were adult by size and should produce eggs. This concept is based on investigations of perch from the 1950s, when the environment as a whole was less affected by human activities than today. In the extensive works by Le Cren $(1951,1958)$ and Alm (1959), all female perch $>19 \mathrm{~cm}$ developed eggs. In fact, background individuals $>19 \mathrm{~cm}$ not developing eggs $\left(\mathrm{GSI}_{\mathrm{SIM}}<1.0 \%\right.$ ) occur only in more recent investigations (Sandström 1994; Sandström et al. 1995; Noaksson et al. 2001, 2004, 2005a; Sandström and Neuman 2003; Roots et al. 2004; Linderoth et al. 2006). The ultimate cause of this phenomenon is unknown, but it has been linked to toxic exposure. Increased frequency of SIM females has been observed for perch exposed to leachate from refuse dumps (Noaksson et al. 2001, 2004, 2005a) and for Atlantic croaker exposed to PAHs (naphthalene and water soluble fractions of diesel fuel oil) in the laboratory (Thomas and Budiantara 1995). Increased SIM frequency has also been related to decreased GSI in SM females, i.e., when both SM and SIM females were available from the same site of investigation (Hansson et al. 2006a; Linderoth et al. 2006).

The increased SIM frequency and decreased GSI in SM females at stations 2-Dynäs lower and 7-Skönvik are indicative of a toxic effect. It is noteworthy that these are the only stations situated close to a kraft pulp mill. Pulp and paper mill effluents constitute complex mixtures and may contain compounds with both estrogenic and androgenic properties (Ellis et al. 2003; Hewitt et al. 2003; Svenson and Allard 2004). Certain effects are also termed "antiestrogenic" and "antiandrogenic," which may or may not be the opposite to the terms "androgenic" and "estrogenic," respectively. Antiestrogenic effects on GSI and plasma estradiol-17 $\beta$ have, in fact, been observed previously in female perch in the recipients of pulp and paper mills (Karels et al. 2001). All together, it seems plausible that the increased SIM frequency and decreased GSI in SM females at 2-Dynäs lower and 7-Skönvik may be related to the kraft pulp mills. Effluents from pulp and paper mills have also been associated with androgenic effects in fish (see references in Pettersson et al. 2007).

\section{Gonad Pigmentation}

The pale gonads, observed at the three Utansjö stations, probably reflect a toxic effect. A similar decrease in gonad pigmentation was observed (although not documented) in several adult female perch from central Stockholm in 2000 and 2001, where the waters were characterised as heavily polluted by a complex mixture of pollutants (Hansson et al. 2006b; Linderoth et al. 2006). The increased gonad pigmentation at station 6-Vivstavarv has not been observed previously, and, to the best of our knowledge, it has not been documented in the literature. The phenomenon requires further investigation, e.g., gonad histology.

\section{Fin Erosion and Skin Ulcers}

Fin erosion is defined as the condition where fins are degraded, frayed, or decreased in size from abrasion, bacterial infections, or fin nipping (Latremouille 2003). Fin necrosis is the process of fins becoming abraded and frayed by way of infection from a variety of bacteria (Latremouille 
2003). Fin rot is the resultant condition from fin necrosis (Latremouille 2003). Fin erosion has been linked i.a. to toxic effects of pulp mill effluents (Lindesjöö and Thulin 1990, 1994) and leachate from refuse dumps (Noaksson et al. 2001, 2005b). It is an unspecific biomarker, probably representing an integrated effect, related to, e.g., decreased condition and/or immunosuppression. The observed fin erosion indicated impaired health at all of the polluted stations. The observation of more severe fin erosion at station 8-Sundsvall than at any other station may reflect the fact that Sundsvall is a relatively large city with many more industries situated close to this station compared with the other polluted stations.

Skin ulcers, which are also an unspecific biomarker, were only observed at station 6-Vivstavarv. It is noteworthy that this station is situated in an area with a history of heavier industrial activity than many of the other polluted stations.

\section{EROD Activity in the Liver}

EROD activity in the liver is a biomarker that responds to exposure to dioxins and dioxin-like pollutants, such as dibenzofurans, certain polychlorinated biphenyls, and many PAHs (Whyte et al. 2000). The increased liver EROD activity at station 1-Dynäs upper in Bollstafjärden is most probably explained by the creosote pollution with particularly high levels close to this station. The bioavailability of this creosote has been showed in an investigation of DNA adducts in perch from this part of Bollstafjärden (Ericson et al. 1999). The increased liver EROD activity at station 3-Utansjö upper may be related to the fact that the area once hosted plenty of saw mills with or without impregnation. There is a possibility that old pollution of PAHs and/or dioxins have become bioavailable during the building of the abutment of the E4 highway bridge, Högakustenbron, which was opened for traffic in 1997. Factors affecting the release and bioavailability of contaminants during sediment-disturbance events have been reviewed by Eggleton and Thomas (2004). The finding that liver EROD levels differed between stations situated as close to each other as $\sim 1 \mathrm{~km}$ may be explained by the fact that the gradient for many PAHs is exponential near the source (Näf et al. 1992).

The decreased liver EROD activity at station 6-Vivstavarv may be explained by the fact that all of these perch had skin ulcers. Such health-impaired fish most probably have a disrupted metabolism and thus disrupted responses to toxicants. As an enzyme activity, EROD activity is affected by all factors from gene transcription and onwards. Loss of liver EROD activity in fish with skin ulcers has also been observed in previous investigations (Lennart Balk, unpublished observations). Liver EROD activity was uncorrelated with the other investigated variables.

\section{Bile Metabolites of Xenohormones}

Pettersson et al. (2007) analysed bile metabolites of the xenohormones bisphenol A and nonylphenol in specimens from Bollstafjärden and Utansjö. These xenoestrogens have often been found in the effluents of STPs (see references in Pettersson et al. 2007). Hence, the fact that the bile concentrations of bisphenol A and nonylphenol in the Utansjö area were highest at the station closest to the local STP supports the hypothesis that these substances were discharged from the STP. However, no corresponding pattern was observed for the Dynäs stations.

\section{Physicochemical Properties of the Water}

The salinity gradient ranged from practically 0 in the river Ångermanälven to $\sim 4.9$ at the Baltic Sea coast. It is unlikely that the differences in salinity between the stations would have had any significant effect on the investigated variables because it has been shown that perch maintains homeostasis up to a salinity of the surrounding water of at least ten (Lutz 1972). For other physicochemical properties, such as temperature and oxygen concentration, the variation was too small to significantly affect the investigated biomarkers.

\section{Societal Significance}

Recent decades have seen an increased interest in the remediation of polluted areas in many parts of the industrialised world, including Sweden. In many countries, the shortage of land available for development has accentuated the need to recapture infrastructural values often associated with former industrial areas. Such infrastructural values include (1) costly investments in water and sewage systems, roads, electricity, and harbours; and (2) proximity to public services. In other instances, remnants of previous industrial activity may block the use of these areas for other purposes or blight otherwise attractive areas, such as waterfront properties (Heinemo 2001). The present investigation shows that even a moderate battery of relatively simple biomarkers may be sufficient to discover biological effects that are probably caused by environmental pollution. This may be important to authorities responsible for the remediation of polluted areas because they often have limited resources for environmental monitoring.

Effects of pulp mill effluents on fish reported from the 1980s and earlier, when elementary chlorine bleaching was common, may not be fully comparable with effects observed in the 2000s because many pulping processes have been modified to meet environmental and other new requirements. 


\section{Conclusion}

The primary objective of this investigation was to test whether environmental pollutants and their associated effects were under control in an industrialised region in Sweden with well-documented environmental pollution from past and present activities. This was determined by measuring biomarkers in adult female perch at several stations in 2003. The results showed that the environmental pollutants and their associated effects were not under control. In fact, the health of the perch was impaired at all of the polluted stations compared with the reference station. Many responses were unspecific with respect to underlying cause(s), whereas some effects on EROD activity and gonad maturation status were attributed to historical creosote pollution and current kraft pulp mill effluents, respectively. Accordingly, even a moderate battery of relatively simple biomarkers may be sufficient to discover biological effects that are probably caused by environmental pollution. This may be important to authorities responsible for the remediation of polluted areas because they often have limited resources for environmental monitoring. The data presented here may also be used as reference values for future investigations of health effects in perch.

Acknowledgments The investigation was partly financed by The Swedish Research Council for Environment, Agricultural Sciences and Spatial Planning. Nils Ekelund supervised Wenche Hansen during a diploma project. Maria Linderoth is kindly acknowledged for determination of the age of the perch. Information about STP loads and pulp and paper production in 2003 was obtained from the respective companies and from the County Administrative Board of Västernorrland (Länsstyrelsen Västernorrland).

Conflict of interest The authors declare that they have no conflict of interest.

\section{References}

Alm G (1959) Connection between maturity, size, and age in fishes. Institute of Freshwater Research, Drottningholm, Fishery Board of Sweden. Report No. 40, p 5-145

Andersson T, Förlin L, Härdig J, Larsson A (1988) Physiological disturbances in fish living in coastal water polluted with bleached kraft pulp mill effluents. Can J Fish Aquat Sci 45:1525-1536

Anonymous (2009) Environmental survey of the sediment in Bollstafjärden [in Swedish]. WSP Samhällsbyggnad, Sundsvall. Mimeo

Anonymous (2010) Regional programme for the work on polluted areas in Västernorrland 2011 [in Swedish]. Länsstyrelsen Västernorrlands län, Härnösand

Balk L, Larsson Å, Förlin L (1996) Baseline studies of biomarkers in the feral female perch (Perca fluviatilis) as tools in biological monitoring of anthropogenic substances. Mar Environ Res $42: 203-208$
Böhling P, Lehtonen H (1985) Effect of environmental factors on migrations of perch (Perca fluviatilis L.) tagged in the coastal waters of Finland. Finn Fish Res 5:31-40

Burke MD, Mayer RT (1974) Ethoxyresorufin: direct fluorimetric assay of a microsomal O-dealkylation which is preferentially inducible by 3-methylcholanthrene. Drug Metab Dispos 2:583-588

Craig JF (1974) Population dynamics of perch, Perca fluviatilis L. in Slapton Ley, Devon. I. Trapping behaviour, reproduction, migration, population estimates, mortality and food. Freshw Biol 4:417-431

Craig JF (1987) The biology of perch and related fish. Croom Helm, London

Eggleton J, Thomas KV (2004) A review of factors affecting the release and bioavailability of contaminants during sediment disturbance events. Environ Int 30:973-980

Ellis RJ, van den Heuvel MR, Smith MA, McCarthy LH, Stuthridge TR, Dietrich DR (2003) In vivo and in vitro assessment of the androgenic potential of a pulp and paper mill effluent. Environ Toxicol Chem 22:1448-1456

Ericson G, Lindesjöö E, Balk L (1998) DNA adducts and histopathological lesions in perch (Perca fluviatilis) and northern pike (Esox lucius) along a polycyclic aromatic hydrocarbon gradient on the Swedish coastline of the Baltic Sea. Can J Fish Aquat Sci $55: 815-824$

Ericson G, Liewenborg B, Lindesjöö E, Näf C, Balk L (1999) DNA adducts in perch (Perca fluviatilis) from a creosote contaminated site in the River Ångermanälven, Sweden. Aquat Toxicol 45:181-193

Forsberg B (2009) The last days of growth-competition between environmental paradigms [in Swedish], 2nd edn. Ruin, Stockholm

Hanson N, Förlin L, Larsson $\AA$ (2009) Evaluation of long-term biomarker data from perch (Perca fluviatilis) in the Baltic Sea suggests increasing exposure to environmental pollutants. Environ Toxicol Chem 28:364-373

Hansson T, Lindesjöö E, Förlin L, Balk L, Bignert A, Larsson $\AA$ (2006a) Long-term monitoring of the health status of female perch (Perca fluviatilis) in the Baltic Sea shows decreased gonad weight and increased hepatic EROD activity. Aquat Toxicol 79:341-355

Hansson T, Schiedek D, Lehtonen KK, Vuorinen PJ, Liewenborg B, Noaksson E et al (2006b) Biochemical biomarkers in adult female perch (Perca fluviatilis) in a chronically polluted gradient in the Stockholm recipient (Sweden). Mar Pollut Bull 53:451-468

Heinemo S- $\AA$ (2001) Investigations of polluted areas 1992-1998 [in Swedish]. Publikation 2001:3, Länsstyrelsen Västernorrlands län, Härnösand

Hewitt LM, Pryce AC, Parrott JL, Marlatt V, Wood C, Oakes K et al (2003) Accumulation of ligands for aryl hydrocarbon and sex steroid receptors in fish exposed to treated effluent from a bleached sulfite/groundwood pulp and paper mill. Environ Toxicol Chem 22:2890-2897

Holm S (1979) A simple sequentially rejective multiple test procedure. Scand J Stat 6:65-70

Huber PJ (1967) The behavior of maximum likelihood estimates under non-standard conditions, In: Proceedings of the Fifth Berkeley Symposium on Mathematical Statistics and Probability, Vol I. University of California Press, Berkeley, p 221-233

Karels A, Markkula E, Oikari A (2001) Reproductive, biochemical, physiological, and population responses in perch (Perca fluviatilis L.) and roach (Rutilus rutilus L.) downstream of two elemental chlorine-free pulp and paper mills. Environ Toxicol Chem 20:1517-1527

Kipling C, Le Cren ED (1984) Mark-recapture experiments on fish in Windermere, 1943-1982. J Fish Biol 24:395-414 
Latremouille DN (2003) Fin erosion in aquaculture and natural environments. Rev Fish Sci 11:315-335

Le Cren ED (1947) The determination of the age and growth of the perch (Perca fluviatilis) from the opercular bone. J Anim Ecol 16:188-204

Le Cren ED (1951) The length-weight relationship and seasonal cycle in gonad weight and condition in the perch (Perca fluviatilis). J Anim Ecol 20:201-219

Le Cren ED (1958) Observations on the growth of perch (Perca fluviatilis L.) over twenty-two years with special reference to the effects of temperature and changes in population density. J Anim Ecol 27:287-334

Linderoth M, Hansson T, Liewenborg B, Sundberg H, Noaksson E, Hanson $\mathrm{M}$ et al (2006) Basic physiological biomarkers in adult female perch (Perca fluviatilis) in a chronically polluted gradient in the Stockholm recipient (Sweden). Mar Pollut Bull 53: $437-450$

Lindesjöö E, Thulin J (1990) Fin erosion of perch Perca fluviatilis and ruffe Gymnocephalus cernua in a pulp mill effluent area. Dis Aquat Org 8:119-126

Lindesjöö E, Thulin J (1994) Histopathology of skin and gills of fish in pulp mill effluents. Dis Aquat Org 18:81-93

Lowry OH, Rosebrough NJ, Farr AL, Randall RJ (1951) Protein measurement with the Folin phenol reagent. J Biol Chem 193:265-275

Lutz PL (1972) Ionic and body compartment responses to increasing salinity in the perch Perca fluviatilis. Comp Biochem Physiol A 42:711-717

Näf C, Broman D, Pettersen H, Rolff C, Zebühr Y (1992) Flux estimates and pattern recognition of particulate polycyclic aromatic hydrocarbons, polychlorinated dibenzo- $p$-dioxins, and dibenzofurans in the waters outside various emission sources on the Swedish Baltic coast. Environ Sci Technol 26:1444-1457

Noaksson E, Tjärnlund U, Bosveld ATC, Balk L (2001) Evidence for endocrine disruption in perch (Perca fluviatilis) in a remote Swedish lake in the vicinity of a public refuse dump. Toxicol Appl Pharmacol 174:160-176

Noaksson E, Gustavsson B, Linderoth M, Zebühr Y, Broman D, Balk L (2004) Gonad development and plasma steroid profiles by HRGC/HRMS during one reproductive cycle in reference and leachate-exposed female perch (Perca fluviatilis). Toxicol Appl Pharmacol 195:247-261

Noaksson E, Linderoth M, Gustavsson B, Zebühr Y, Balk L (2005a) Reproductive status in female perch (Perca fluviatilis) outside a sewage treatment plant processing leachate from a refuse dump. Sci Total Environ 340:97-112
Noaksson E, Linderoth M, Tjärnlund U, Balk L (2005b) Toxicological effects and reproductive impairments in female perch (Perca fluviatilis) exposed to leachate from Swedish refuse dumps. Aquat Toxicol 75:162-177

Pettersson M, Hahlbeck E, Katsiadaki I, Asplund L, Bengtsson B-E (2007) Survey of estrogenic and androgenic disruption in Swedish coastal waters by the analysis of bile fluid from perch and biomarkers in the three-spined stickleback. Mar Pollut Bull $54: 1868-1880$

Roots O, Järv L, Simm M (2004) DDT and PCB concentrations dependency on the biology and domicile of fish: an example of perch (Perca fluviatilis L.) in Estonian coastal sea. Fresenius Environ Bull 13:620-625

Sandström O (1994) Incomplete recovery in a coastal fish community exposed to effluent from a modernized Swedish bleached kraft mill. Can J Fish Aquat Sci 51:2195-2202

Sandström O, Neuman E (2003) Long-term development in a Baltic fish community exposed to bleached pulp mill effluent. Aquat Ecol 37:267-276

Sandström O, Neuman E, Thoresson G (1995) Effects of temperature on life history variables in perch. J Fish Biol 47:652-670

Sandström O, Larsson A, Andersson J, Appelberg M, Bignert A, Ek H et al (2005) Three decades of Swedish experience demonstrates the need for integrated long-term monitoring of fish in marine coastal areas. Water Qual Res J Can 40:233-250

Sundström G, Larsson Å, Tarkpea M (1986) Creosote. In: Hutzinger $\mathrm{O}$ (ed) The handbook of environmental chemistry, Vol 3/Part D. Springer, Berlin, pp 159-205

Svenson A, Allard AS (2004) In vitro androgenicity in pulp and paper mill effluents. Environ Toxicol 19:510-517

Thomas P, Budiantara L (1995) Reproductive life history stages sensitive to oil and naphthalene in Atlantic croaker. Mar Environ Res 39:147-150

van der Oost R, Beyer J, Vermeulen NPE (2003) Fish bioaccumulation and biomarkers in environmental risk assessment: a review. Environ Toxicol Pharmacol 13:57-149

White H (1980) A heteroskedasticity-consistent covariance matrix estimator and a direct test for heteroskedasticity. Econometrica 48:817-838

White H (1982) Maximum likelihood estimation of misspecified models. Econometrica 50:1-25

Whyte JJ, Jung RE, Schmitt CJ, Tillitt DE (2000) Ethoxyresorufin- $O$ deethylase (EROD) activity in fish as a biomarker of chemical exposure. Crit Rev Toxicol 30:347-570 